\title{
Sistem Informasi Geografis Persebaran Penyakit Rabies di Kabupaten Sintang Menggunakan Metode Small Area Estimation
}

\author{
Dawami Al Nazhari ${ }^{\# 1}$, M. Azhar Irwansyah ${ }^{\# 2}$, Haried Novriando ${ }^{\# 3}$

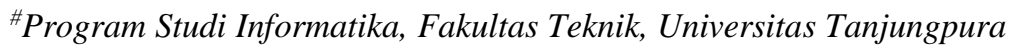 \\ Jl. Prof. Dr. H. Hadari Nawawi, Pontianak 78124 \\ ${ }^{1}$ dalnazhariegmail.com \\ 2azharirwansyaheinformatika.untan.ac.id \\ 3hariedeinformatika. untan.ac.id
}

\begin{abstract}
Abstrak
Rabies adalah penyakit infeksi tingkat akut pada susunan saraf pusat yang disebabkan oleh virus rabies. GIS dapat membantu mendefinisikan zona-zona dalam bentuk satuan pemetaan, memodelkan pola dan arah gerakan atau penyebaran suatu penyakit. Tujuan dari penelitian ini adalah membangun sebuah Sistem Informasi Geografis yang dapat memberikan informasi persebaran penyakit rabies berdasarkan desa yang ada di Kabupaten Sintang. Penelitian ini menggunakan metode pendugaan yaitu Small Area Estimation dan menggunakan pendekatan Empirical Bayes. Hal yang harus dilakukan pertama dalam pendekatan Empirical Bayes adalah menentukan indikator parameter, hewan penyebar rabies (X1), hewan penyebar tervaksin (X2), dan jumlah kasus gigitan hewan penyebar rabies (X3). Kemudian dicari korelasi antar indikator dan dilakukan perhitungan nilai dugaan untuk mencari nilai MSE sebaran penyakit rabies perdesa. Metode ini dinilai sesuai dalam memetakan persebaran penyakit rabies agar dapat mempermudah masyakat dalam mencari informasi mengenai sebaran penyakit rabies. Hasil dari sistem ini adalah sebaran penyakit rabies yang ada di Kabupaten Sintang ditampilkan sebagai peta dalam sistem informasi geografis. Berdasarkan sistem analisis didapatkan sebaran dalam status paling tinggi dan bahaya ada pada 3 desa Senangan Kecil, Tanjung Puri, dan Kapuas Kanan Hulu dengan nilai MSE 0,040481928 di mana semakin besar nilai MSE dari 0 maka semakin besar potensi terjadinya rabies pada suatu desa. Maka dari itu, dapat disimpulkan bahwa pengujian sistem menggunakan black box menunjukan sistem berjalan sesuai dengan yang di harapkan dan dari hasil kuesioner dengan 15 responden memiliki persentase dengan rata-rata $88 \%$ berdasarkan skala likert menunjukan bahwa sistem berada dalam kategori baik.
\end{abstract}

Kata Kunci: Kabupaten Sintang, Sistem Informasi Geografis, Small Area Estimation, Empirical Bayes, Indikator, Hewan Penyebar Rabies

\section{Geographic Information System for the Distribution of Rabies in Sintang District Using the Small Area Estimation Method}

\begin{abstract}
Rabies is an acute infection in the central nervous system caused by the rabies virus. GIS can help define zones in the form of mapping units, modeling the pattern and direction of movement or spread of a disease. The purpose of this study is to develop a Geographic Information System that can provide information on the spread of rabies based on villages in Sintang District. This research uses the estimation method that is Small Area Estimation and uses the Empirical Bayes approach. The first thing to do in the Empirical Bayes approach is to determine parameter indicators, rabies-spreading animals (X1), vaccinated spreading animals (X2), and the number of bite cases of rabies-spreading animals (X3). Then the correlation between indicators is sought and the estimated value is calculated to find the MSE value of the distribution of rural rabies. This method is considered appropriate in mapping the distribution of rabies in order to facilitate the community in finding information about the distribution of rabies. The result of this system is the distribution of rabies in Sintang District displayed as a map in the geographic information system. Based on the analysis system, it was found that the distribution was in the highest status and the danger was in 3 villages of Senangan Kecil, Tanjung Puri, and Kapuas Kanan Hulu with an MSE value of 0.040481928 where the greater the MSE value from 0 , the greater the potential for
\end{abstract}


rabies to occur in a village. Therefore, it can be concluded that the system testing using black box shows the system is running as expected and from the results of a questionnaire with 15 respondents has a percentage with an average of $88 \%$ based on the Likert scale shows that the system is in good category.

Keywords: Sintang District, Geographic Information System, Small Area Estimation, Rabies, Empirical Bayes, Indicators, Rabies-Spreading Animals

\section{PENDAhUluan}

Rabies di Kabupaten Sintang merupakan masalah kesehatan masyarakat yang serius karena hampir selalu menyebabkan kematian setelah timbul gejala klinis dengan tingkat kematian sampai $100 \%$. Berdasarkan data dari Dinas Kesehatan Kabupaten Sintang Kejadian Luar Biasa (KLB) rabies di Kabupaten Sintang dari tahun 2014-2016 tercatat 232 gigitan hewan penular rabies pada manusia dan 4 orang meninggal. Pada tahun 2017 data kasus kematian yang disebabkan rabies di Kabupaten Sintang tercatat sekitar 135 kasus gigitan anjing. Karena luasnya wilayah Sintang yang terdiri dari 14 wilayah kecamatan maka di- perlukannya pemetaan terhadap penyakit rabies tersebut, agar dapat mempermudah instansi terkait dalam mengatasi wabah penyakit rabies.

Berdasarkan masalah-masalah yang dikemukakan di atas yang menjadi dasar pembangunan "Sistem Informasi Geografis Persebaran Penyakit Rabies Di Kabupaten Sintang Menggunakan Metode Small Area Estimation" untuk menjadi solusi permasalahan yang ada. Kompleksitas dalam memahami fenomena penyakit dalam ruang, merupakan perencanaan wilayah dan tugas yang sangat rumit. Saat ini GIS dapat membantu mendefinisikan zona-zona dalam bentuk satuan pemetaan, memodelkan pola dan arah gerakan atau penyebaran suatu penyakit.

Dalam melakukan optimalisasi data yang tersedia dengan menggunakan metode pendugaan yaitu Small Area Estimation. SAE merupakan proses penting dalam sampling terutama dalam estimasi parameter tidak langsung. Digunakan ukuran sampel relatif kecil. Metode ini dapat mengestimasi karakteristik dari sub populasi (domain yang lebih kecil dalam populasi) [1]. Metode ini dikembangkan dengan menghubungkan informasi dari daerah tertentu dengan daerah-daerah lain melalui model pendekatan. Prosedur ini disebut estimasi tidak langsung. Jadi model SAE meminjam informasi dari sampel observasi melalui data bantu (data sensus atau catatan administrasi terbaru) untuk meningkatan efektivitas ukuran sampel [2].

Meningkatnya suatu kasus atau kejadian disebabkan kurang fokus atau kurang tepatnya suatu program pengendalian. Dengan adanya Sistem Informasi Geografis ini program pemerintah dapat tepat sasaran dalam menangani persebaran penyakit rabies di wilayah Kabupaten Sintang.

Menurut penelitian terdahulu Sistem Informasi Geografis yang dibangun hanya menampilkan titik penderita raibies tanpa di lakukannya analisis. Sedangkan penelitian ini menghasilkan sistem informasi geografis dengan menggunakan metode small area estimatiton. Sehingga dapat menentukan desa-desa yang dalam kondisi bahaya rabies dengan mengambil beberapa faktor dari luar desa itu sendiri. Jadi sistem informasi geografis ini bisa mendapatkan informasi mengenai peta di daerah tertentu berdasarkan kriteria pencarian yang tersedia.

\section{Metodologi Penelitian}

\section{A. Metode Penelitian}

Metodologi penelitian merupakan suatu perencanaan penelitian yang akan dilakukan secara sistematis dan ilmiah. Proses tersebut dilakukan dengan mendesain perencanaan penelitian sesuai dengan tahapan penelitian yang dilakukan. Metodologi penelitian tersebut diilustrasikan pada Gambar 1.

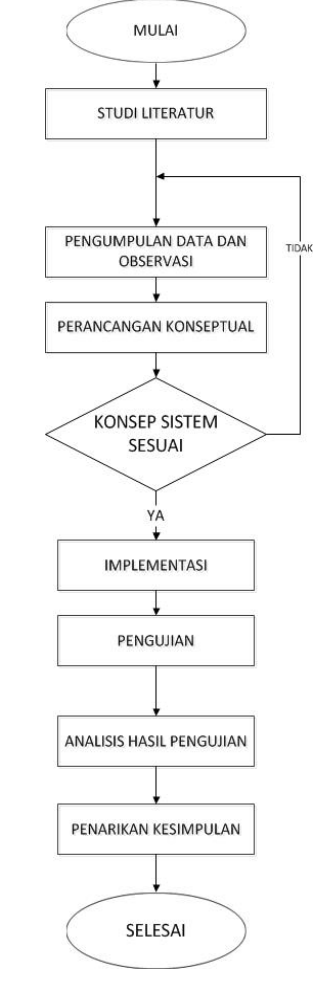

Gambar. 1 Metode penelitian

\section{B. Diagram Alir Sistem}

Diagram Alir sistem merupakan diagram yang menggambarkan sistem yang akan dibangun. Adapun diagram alir sitem yang akan dibangun dapat dilihat pada Gambar 2.

Website akan menampilkan data sebaran penyakit rabies kepada masyarakat umum. Kemudian admin mengelola data dengan melakukan login, data akan diinputkan oleh admin lalu data yang telah input akan dilakukan perhitungan dengan metode Small Area Estimation berdasarkan lokasi titik, jumlah hewan penyebar rabies, jumlah hewan penyebar rabies tervaksin, dan jumlah titik kasus sebaran penyakit rabies. 


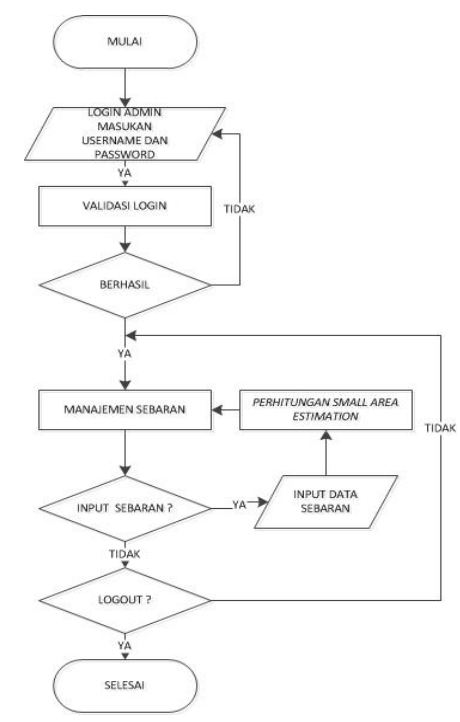

Gambar. 2 Diagram Alir Sistem Informasi Geografis Persebaran Penyakit Rabies di Kabupaten Sintang

\section{Diagram Konteks}

Diagram konteks adalah diagram yang memberikan gambaran umum terhadap kegiatan yang berlangsung dalam sistem [1].

Diagram konteks sistem adalah diagram yang memberi gambaran seluruh jaringan terhadap seluruh masukan dan keluaran sistem yang dimaksudkan untuk mengambarkan sistem yang sedang berjalan. Diagram konteks Sistem Informasi Geografis yang dirancang dapat dilihat pada Gambar 3.

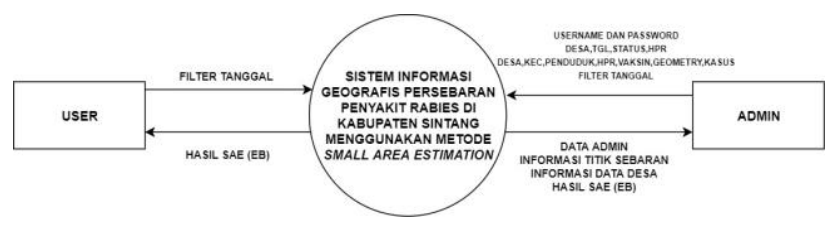

Gambar. 3 Diagram konteks sistem

\section{Diagram Overview}

Diagram overview adalah diagram yang menggambarkan proses dari diagram arus data. Diagram overview memberikan pandangan secara menyeluruh mengenai rancangan Sistem Informasi Geografis Persebaran Penyakit Rabies di Kabupaten Sintang Menggunakan Metode Small Area Estimation (lihat Gambar 4).

Pada proses 1.0 admin akan melakukan login dengan memasukan username dan password, kemudian admin dapat mengubah password admin. Pada proses 2.0 admin dapat menambahkan, merubah, dan menghapus data titik sebaran. Pada proses 3.0 admin dapat menambah, merubah, dan menghapus data desa. Pada proses 4.0 Sistem akan melakukan perhitungan Small Area Estimation yang nantinya akan ditampilkan ke user.

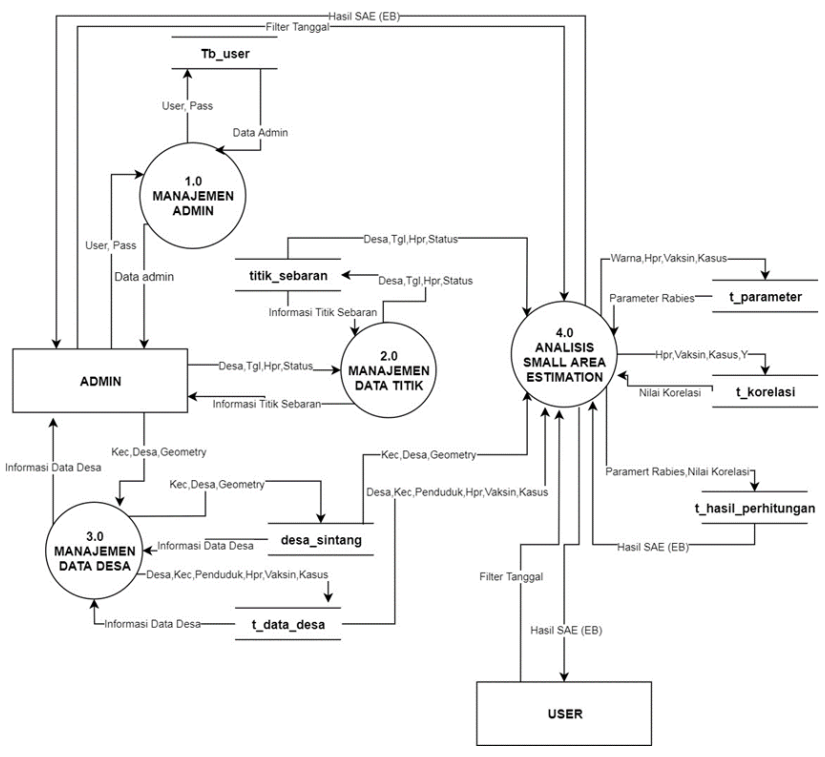

Gambar. 4 Diagram overview sistem

\section{E. Sistem}

Beberapa definisi sistem yaitu suatu hubungan kerja dari prosedur yang saling berkaitan, berkumpul bersamasama untuk melakukan suatu kegiatan atau untuk menyelesaikan suatu sasaran tertentu. Sistem secara umum dapat didefinisikan sebagai kumpulan hal atau elemen yang saling bekerja sama atau yang dihubungkan dengan cara-cara tertentu sehingga membentuk satu kesatuan untuk melaksanakan suatu fungsi guna mencapai suatu tujuan. Sistem mempunyai karakteristik atau sifatsifat tertentu yaitu: komponen sistem, batasan sistem, lingkungan luar sistem, penghubung sistem, masukan sistem, keluaran sistem, pengolahan system, dan sasaran sistem [3]. Definisi lainnya mengenai sistem yaitu sekelompok bagian yang disusun dan diatur dengan baik yang bekerja sama untuk melakukan suatu maksud. Dan sistem juga merupakan suatu grup dari elemen-elemen baik yang berbentuk fisik maupun bukan fisik yang menunjukkan suatu kumpulan yang saling berhubungan dan berinteraksi bersama-sama menuju satu atau lebih tujuan, sasaran, atau akhir dari sistem.

\section{F. Informasi}

Pengertian Informasi adalah sebagai berikut: "Informasi diartikan sebagai data yang diolah menjadi bentuk yang lebih berguna dan lebih berarti bagi yang menerimanya". Jadi Informasi adalah data yang diproses kedalam bentuk yang lebih berarti bagi penerima dan berguna dalam pengambilan keputusan, sekarang atau untuk masa yang akan datang [4].

\section{G. Sistem Informasi}

Sistem informasi adalah suatu sistem didalam suatu organisasi yang mempertemukan kebutuhan pengolahan transaksi harian yang mendukung fungsi operasi organisasi yang bersifat manajerial dengan kegiatan strategi dari suatu organisasi untuk dapat menyediakan kepada pihak luar tertentu dengan laporan-laporan yang diperlukan [5]. 


\section{H. Sistem Informasi Geografis}

Secara teknis SIG mengorganisasikan dan memanfaatkan data dari peta digital yang tersimpan dalam basis data. Dalam SIG, dunia nyata dijabarkan dalam data peta digital yang menggambarkan posisi dari ruang (space) dan klasifikasi, atribut data, dan hubungan antar item data. Kerincian data dalam SIG ditentukan oleh besarnya satuan pemetaan terkecil yang dihimpun dalam basis data. Dalam bahasa pemetan kerincian tergantung dari skala peta dan dasar acuan geografis yang disebut sebagai peta dasar [6].

\section{Parameter Penyakit Rabies}

1) Hewan Penyebar rabies menjadi salah satu indikator utama dalam penentuan persebaran penyakit rabies pada suatu daerah dengan pengelompokan kelas sebagai dapat dilihat pada Tabel I.

TABEL I

PARAMETER HEWAN PENYEBAR RABIES

\begin{tabular}{|c|c|}
\hline Parameter & Nilai \\
\hline Aman & $<20 \mathrm{HPR}$ \\
\hline Waspada & $>20 \mathrm{HPR}<40 \mathrm{HPR}$ \\
\hline Siaga & $>40<60 \mathrm{HPR}$ \\
\hline Bahaya & $>60<80 \mathrm{HPR}$ \\
\hline Sangat Bahaya & $>80 \mathrm{HPR}$ \\
\hline
\end{tabular}

Sumber: Pusat Data dan Informasi Kementrian Kesehatan RI

2) Hewan Penyebar rabies tervaksin menjadi salah satu indikator utama dalam penentuan persebaran penyakit rabies pada suatu daerah dengan pengelompokan kelas dapat dilihat pada Tabel II.

TABEL II

PARAMETER HEWAN PENYEBAR RABIES TERVAKSIN

\begin{tabular}{|c|c|}
\hline Parameter & Nilai \\
\hline Aman & $>80 \mathrm{HPR}$ \\
\hline Waspada & $>60 \mathrm{HPR}<80 \mathrm{HPR}$ \\
\hline Siaga & $>40<60 \mathrm{HPR}$ \\
\hline Bahaya & $>20<40 \mathrm{HPR}$ \\
\hline Sangat Bahaya & $<20 \mathrm{HPR}$ \\
\hline
\end{tabular}

Sumber: Pusat Data Dan Informasi Kementrian Kesehatan RI

3) Jumlah kasus gigitan hewan penyebar rabies menjadi salah satu indikator utama dalam penentuan persebaran penyakit rabies pada suatu daerah dengan pengelompokan kelas disesuaikan dengan jumlah gigitan perdesa dapat dilihat Pada Tabel III.

TABEL III

Parameter Kasus Gigitan Hewan PenYebar Rabies

\begin{tabular}{|c|c|}
\hline Parameter & Nilai \\
\hline Aman & $<2$ GHPR \\
\hline Waspada & $>3$ GHPR $<5$ GHPR \\
\hline Siaga & $>6<9$ GHPR \\
\hline Bahaya & $>10<12$ GHPR \\
\hline Sangat Bahaya & GHP \\
\hline
\end{tabular}

Sumber: Pusat Data Dan Informasi Kementrian Kesehatan RI

\section{J. Small Area Estimation}

Small Area Estimation (SAE) adalah suatu teknik statistika untuk menduga parameter-parameter sub populasi yang ukuran sampelnya kecil. Sedangkan, area kecil didefinisikan sebagai himpunan bagian dari populasi (sub populasi) yang ukuran contohnya kecil dengan suatu peubah menjadi perhatian [2]. Area kecil tersebut dapat berupa kota, kabupaten, kecamatan, desa/kelurahan, kelompok suku, kelompok jenis kelamin atau kelompok umur. Pendugaan area kecil merupakan konsep terpenting dalam pendugaan parameter di suatu area yang relatif kecil dalam percontohan survei (survey sampling).

Pendugaan relatif dan inferensinya yang menggunakan informasi tambahan tersebut, dinamakan pendugaan tidak langsung (indirect estimation atau model-based estimation). Metode dengan memanfaatkan informasi tambahan tersebut secara relatif memiliki sifat "meminjam kekuatan" (borrowing strength) informasi dari hubungan antara peubah respon dengan informasi yang ditambahkan. Dengan demikian, pendugaan tidak langsung ini mencakup data dari domain yang lain [7]. Prosedur pendugaan area kecil pada dasarnya memanfaatkan kekuatan informasi area sekitarnya (neighbouring areas) dan sumber data di luar area yang statistiknya ingin diperoleh melalui pembentukan model yang tepat untuk meningkatkan efektifitas ukuran contoh. Secara umum, Small Area Estimation (SAE) atau pendugaan area kecil dapat dikatakan sebagai suatu metode untuk menduga parameter pada suatu area yang relatif kecil dalam percontohan survei dengan memanfaatkan informasi dari luar area, dari dalam area itu sendiri dan dari luar survei.

Berdasarkan model dasar pendugaan area kecil [8], penduga terbaik (Best Prediction, BP) bagi parameter yang menjadi perhatian pada area ke-i $(\theta \mathrm{i})$ dengan meminimumkan kuadrat tengah galat (Mean Square Error, MSE). Dengan kata lain hasil dugaan terbaik adalah yang mempunyai nilai MSE minimum. Untuk mendapatkan nilai MSE pada pendekatan SAE maka digunakan metode Emperical Bayes (EB).

Metode Emperical Bayes (EB) merupakan salah satu metode pendekatan yang dapat digunakan pada pendugaan area kecil. Hal pertama yang ingin didapatkan pada metode Bayes adalah sebaran posterior untuk parameter yang diamati yang dinotasikan $\mathrm{f}\left(\theta i \mid y i, \beta, \sigma^{2} v\right)$, dengan asumsi $\beta$ dan $\sigma^{2} v$ diketahui. Sedangkan pada metode EB, inferensia yang diperoleh berdasarkan pada dugaan sebaran posterior dari $\theta i$ dengan memasukkan dugaan $\beta$ dan $\sigma^{2} v$ yaitu $\mathrm{f}\left(\theta i \mid y i, \beta, \sigma^{2} v\right)$

Model [7] untuk model Basic Area Level adalah : $y i=x_{i}^{T} \beta+v_{i}+e_{i}$

dimana $\beta$ adalah vektor parameter korelasi regresi, $v_{i} \sim \mathrm{N}$ $\left(0, \sigma^{2} v\right)$ dan $\theta_{\mathrm{i}} \sim \mathrm{N}\left(0, \sigma^{2} v\right) \nu_{\mathrm{i}}$ dan $\theta_{\mathrm{i}}$ saling bebas. $\beta$ dan $\sigma^{2} v$ tidak diketahui sedangkan $\sigma^{2} e i$ diasumsikan diketahui (Kurnia dan Notodiputro, 2006).

Misal $\sigma^{2} v$ dan $\sigma^{2} e \mathrm{i}$ disimbolkan dengan $\mathrm{A}$ dan $D_{\mathrm{i}}$, selanjutnya $\theta i^{B}$ merupakan penduga bayes untuk $\theta i$, dengan mengikuti model bayes : 


$$
y_{i} \mid \theta i \sim N\left(\theta i, D_{i}\right)
$$

(ii)

$$
\begin{aligned}
& \theta i \sim N\left(x_{i}{ }^{T} \beta_{s} A\right) \text { adalah sebaran prior untuk } \\
& \theta i, i=1,2 \ldots, m
\end{aligned}
$$

Model Bayes dijelaskan:

$f\left(y_{i} \| \theta i\right)=\frac{1}{\sqrt{2 \pi D_{i}}} \exp \left(-\frac{1}{2 D_{i}^{i}}\left(y_{i}-\theta i\right)^{2}\right)$ dan

$\pi(\theta i)=\frac{1}{\sqrt{2 \pi A}} \exp \left(-\frac{1}{2 A}(\theta i-x i \beta)^{2}\right)$ dan

$f\left(y_{1}, \theta i \mid \beta, A\right)=\Pi \frac{1}{\sqrt{2 \pi D_{i}}} \exp \left(-\frac{1}{\sqrt{2 \pi D_{i}}}\left(y_{i}-\right.\right.$

$\left.\theta i)^{2}\right) \frac{1}{\sqrt{2 \pi A}} \exp \left(-\frac{1}{2 A}(\theta i-x i \beta)^{2}\right)$

untuk $y_{i}=\left(y_{1}, y_{2 \ldots} y_{m}\right)^{T}$ dan $\theta i=\left(\theta_{1,} \theta_{2,} \ldots \theta_{m}\right)^{T}$

Lihat dua fungsi eksponensial tanpa faktor (-1/2) dari

$f\left(y_{\mathrm{i}}, \theta i \mid \beta, A\right)$,

$\frac{1}{D_{i}}\left(y_{i}-\theta i\right)^{2}+\frac{1}{A}(\theta i-x i \beta)^{2}$

$=\frac{1}{D_{i}}\left(y_{i^{2}}-2 y_{i} \theta i+\theta i^{2}\right)+\frac{1}{A}\left(\theta i^{2}-2 \theta i x i \beta+(x i \beta)^{2}\right)$

$=\left(\frac{1}{D_{\bar{i}}}+\frac{1}{A}\right) \theta i^{2}-2\left(\frac{y_{i}}{D_{\bar{i}}}+\frac{x i \beta}{A}\right) \theta i+a i$

$=\left(\frac{1}{b_{i}}+\frac{1}{A}\right)+\left(\theta i^{2}-\left(2 \theta i \frac{\left(\frac{y_{i}}{b_{i}}+\frac{x i g}{A}\right)}{\left(\frac{1}{D_{i}}+\frac{1}{A}\right)}\right)+\right.$

$\left(\frac{\left(\frac{\underline{V}_{i}}{D_{i}}+\frac{x i g}{A}\right)}{\left(\frac{1}{D_{i}}+\frac{1}{A}\right)}\right)\left(\frac{\left(\frac{y_{i}}{D_{i}}+\frac{x i g}{A}\right)}{\left(\frac{1}{D_{i}}+\frac{1}{A}\right)}\right)+a i$

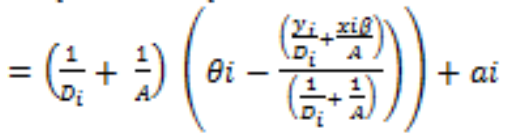

Dengan ai adalah konstanta bebas dari $\theta i$

$\left.\left(\theta_{\mathrm{i}} \mid y_{\mathrm{i}}, \beta_{x} A\right) \sim N\left(\frac{A y_{\mathrm{i}}+D_{\mathrm{i}} x i \beta}{A+D_{\mathrm{i}}}\right),\left(\left(\frac{1}{D_{\mathrm{i}}}+\frac{1}{A}\right)\right)-1\right)$

$\left(\theta_{\mathrm{i}} \mid y_{\mathrm{i}}, \beta, A\right) \sim N\left(x i \beta \frac{A}{A+D_{\mathrm{i}}}\left(y_{\mathrm{i}}-x i \beta\right), \frac{A D_{\mathrm{i}}}{A+D_{\mathrm{i}}}\right)$

Berdasarkan formula tersebut maka akan diperoleh suatu penduga:

$\theta i^{B}=E\left(\theta_{i} \mid y_{i}, \beta, A\right)=x i \beta+\left(1-B_{i}\right)\left(y_{i}-x i \beta\right)$, dengan

$B_{i}=D_{i} /\left(A+D_{i}\right)$

Berdasarkan metode Bayes maka diperoleh :

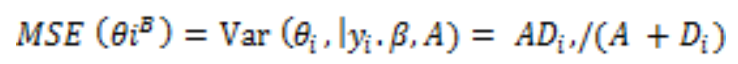

Jika $A$ dan $\beta$ diduga, maka akan diperoleh suatu penduga Empirical Bayes:

$\theta i^{E B}=\Sigma\left(\theta_{i} \mid x_{i}, b_{i}\right)=b_{i} x_{i}+b_{i+1} x_{i+1}+\ldots+b_{i+m} x_{i+m}$

$\operatorname{MSE}=\left(\theta i^{E B}\right)=\Sigma\left(\left(\theta_{i}, \mid y_{v} x_{i}, \theta i^{E B}\right)=y \frac{\theta_{i}^{E B}}{\left(y+\theta_{i}^{E B}\right)}\right.$
Adapun tahapan-tahapan yang dilakukan untuk mendapatkan pendugaan terhadap rabies:

1. Memilih indikator respon atau utama dan indikator pendukung yang diasumsikan mempengaruhi penilaian terhadap penyakit rabies.

2. Menduga potensi penyakit rabies pada masing-masing desa.

3. Menghitung nilai MSE pada masing-masing desa.

4. Membandingkan nilai MSE terhadap masing-masing desa.

Pada tahapan pertama, yaitu memilih indikator utama dan indicator pendukung yang diasumsikan mempengaruhi penilaian terhadap penyakit rabies. Untuk dapat memilih indikator utama dan indikator pendukung dilakukan dengan melakukan eksplorasi terhadap data menggunakan nilai korelasi regresi. Korelasi adalah salah satu teknik statistik yang digunakan untuk mencari hubungan antara dua variabel atau lebih yang sifatnya kuantitatif. Tingkat keeratan hubungan atau koefisien korelasi bergerak dari 0-1. Jika nilai korelasi mendekati 1 misalnya 0,95 ini dapat dikatakan bahwa memiliki hubungan yang sangat erat Sebaliknya, jika mendekati 0 misalnya 0,10 dapat dikatakan mempunyai hubungan yang rendah. Nilai korelasi mempunyai harga - 1 hingga +1. Harga -1 menunjukan adanya hubungan yang sempurna bersifat terbalik antara kedua variabel. Sedangkan hubungan +1 menunjukan adanya hubungan sempurna positif [9].

Nilai korelasi regresi didapatkan dari perhitungan menggunakan Minitab. Minitab adalah program komputer yang dirancang untuk melakukan pengolahan Statistik. Minitab mengkombinasikan kemudahan penggunaan layaknya Microsoft Excel dengan kemampuannya melakukan analisa statistik yang kompleks.

Pada tahapan kedua, yaitu menduga potensi persebaran penyakit rabies untuk masing-masing desa. Untuk dari tahapan ketiga menghasilkan nilai MSE untuk masingmasing desa. Untuk mendapatkan nilai dugaan dan nilai MSE pada masing-masing desa digunakan metode EB dengan rumus (1) dan (2).

Pada tahapan ketiga didapatkan nilai MSE dari masing-masing desa dan pada tahapan keempat akan dilakukan perbandingan terhadap parameter parameter yang mempengaruhi. Hasil dugaan yang terbaik adalah yang mempunyai nilai MSE yang minimum untuk wilayah aman.

Pada tahap keempat nilai MSE yang telah didapatkan kemudian dibandingkan pada setiap desa yang ada sehingga dapat diketahui desa-desa mana saja yang menjadi prioritas untuk dilakukan penanganan penyakit rabies.

\section{K. Hypertext Markup Language}

HTML kependekan Hyper Text Markup Language. Dokumen HTML adalah textfile murni yang dapat dibuat dengan editor text sembarang. Dokumen ini dikenal sebagai web page. File-file HTML ini berisi instruksiinstruksi yang kemudian diterjemahkan oleh browser yang ada di komputer client(user) sehingga isi informasinya 
dapat ditampilkan secara visual di komputer pengguna (user).

\section{Cascading Style Sheet}

"CSS merupakan singkatan dari Cascading Style Sheet. Kegunaannya adalah untuk mengatur tampilan dokumen HTML, contohnya seperti pengaturan jarak antar baris, teks, warna dan format border bahkan penampilan file gambar. CSS dikembangkan oleh W3C. Organisasi yang mengembangkan teknologi internet. Tujuannya tak lain untuk mempermudah proses penataan halaman web [10].

\section{Hypertext Preprocessor}

PHP disebut bahasa pemrograman server-side karena PHP diproses pada komputer server. Hal ini berbeda dibandingkan dengan bahasa pemrograman client-side seperti JavaScript yang diproses pada web browser (client). "Hypertext Preprocessor (PHP) yaitu bahasa pemograman web server-side yang bersifat open source". PHP merupakan script yang terintegrasi dengan HTML dan berada pada server (server side HTML embedded scripting) [11].

PHP dirancang untuk membentuk web dinamis, gunanya membentuk suatu tampilan berdasarkan permintaan terkini. Untuk sebuah web jika menggunakan bahasa pemrograman PHP maka akan menjadi lebih dinamis dan rapi. kode PHP biasanya disisipkan kedalam file HTML, karena itu PHP disebut juga sebagai Scripting Language atau bahasa pemrograman script.

\section{N. JQuery}

JQuery merupakan sebuah Library Javascript yang cepat dan ringkas yang mana dapat menyederhanakan document traversing, event handling, animating, dan AJAX interactions untuk pengembangan web secara cepat.

JQuery merupakan pustaka JavaScript yang dibangun untuk mempercepat dan memperingkas serta menyederhanakan manipulasi dokumen HTML, penanganan event, animasi dan interaksi Ajax untuk mempercepat pengembangan web [12].

\section{O. $M y S Q L$}

MySQL adalah sistem manajemen database SQL yang bersifat Open Source dan paling populer saat ini. Sistem Database MySQL mendukung beberapa fitur seperti multithread, multi-user, dan SQL Database Management System (DBMS).

MySQL adalah sebuah sistem manajemen database relasi (Relational Database Management System) yang bersifat open source. Server MySQL mengontrol akses data sehingga dapat diakses oleh banyak pengguna secara bersamaan, menyediakan akses yang cepat, dan memastikan hanya penguna yang terotorisasi yang dapat mengakses basis data. MySQL menggunakan SQL (Structured Query Language) [13].

\section{P. Basis Data}

Basis Data adalah kumpulan data (elementer) yang secara logika berkaitan dalam merepresentasikan fenomena/fakta secara terstruktur dalam domain tertentu untuk mendukung aplikasi pada sistem tertentu [14].

\section{Q. Google Maps Application Programming Interface} (API)

Merupakan suatu fitur aplikasi yang dikeluarkan oleh Google untuk memfasilitasi pengguna yang ingin mengintegrasikan Google Maps ke dalam website masingmasing dengan menampilkan data point milik sendiri. Dengan menggunakan Google Maps API, Google Maps dapat ditanamkan pada website eksternal. Agar aplikasi Google Maps dapat muncul di website tertentu, diperlukan adanya API key. API key merupakan kode unik yang digenerasikan oleh google untuk suatu website tertentu, agar server Google Maps dapat mengenali.

\section{R. $D F D$}

DFD merupakan suatu cara atau metode untuk membuat rancangan sebuah sistem yang mana berorientasi pada alur data yang bergerak pada sebuah sistem nantinya (lihat Tabel IV).

Data Flow Diagram (DFD) adalah sebuah alat yang menggambarkan aliran data sampai sebuah sistem selesai, dan kerja atau proses dilakukan dalam sistem tersebut [15]

Basis Data ada beberapa simbol digunakan pada DFD untuk mewakili [16]

1) Kesatuan Luar (External Entity)

Kesatuan luar (external entity) merupakan kesatuan (entity) di lingkungan luar sistem yang dapat berupa orang, organisasi, atau sistem lain yang berada pada lingkungan luarnya yang memberikan input atau menerima output dari sistem.

2) Arus Data (Data Flow)

Arus Data (data flow) di DFD diberi simbol suatu panah. Arus data ini mengalir di antara proses, simpan data, dan kesatuan luar. Arus data ini menunjukan arus dari data yang dapat berupa masukan untuk sistem atau hasil dari proses sistem.

3) Proses (Process)

Proses (process) menunjukan pada bagian yang mengubah input menjadi output, yaitu menunjukan bagaimana satu atau lebih input diubah menjadi beberapa output. Setiap proses mempunyai nama, nama dari proses ini menunjukan apa yang dikerjakan proses.

4) Simpanan Data (Data Store)

Data Store merupakan simpanan dari data yang dapat berupa suatu file atau database pada sistem komputer. 
TABEL IV

SIMBOL DFD

\begin{tabular}{|c|c|}
\hline Simbol DFD & Nama \\
\hline & $\begin{array}{c}\text { Entitas / Kesatuan } \\
\text { luar }\end{array}$ \\
\hline & Proses \\
\hline & $\begin{array}{c}\text { Arus data / Aliran } \\
\text { data }\end{array}$ \\
\hline Data & $\begin{array}{c}\text { Data store / } \\
\text { Simpanan data }\end{array}$ \\
\hline
\end{tabular}

\section{S. Flowchart}

Flowchart merupakan penggambaran secara grafik dari langkah-langkah dan urutan prosedur suatu program (lihat Tabel V). Biasanya mempermudah penyelesaian masalah yang khususnya perlu dipelajari dan dievaluasi lebih lanjut [14].

TABEL V

SIMBOL FLOWCHART

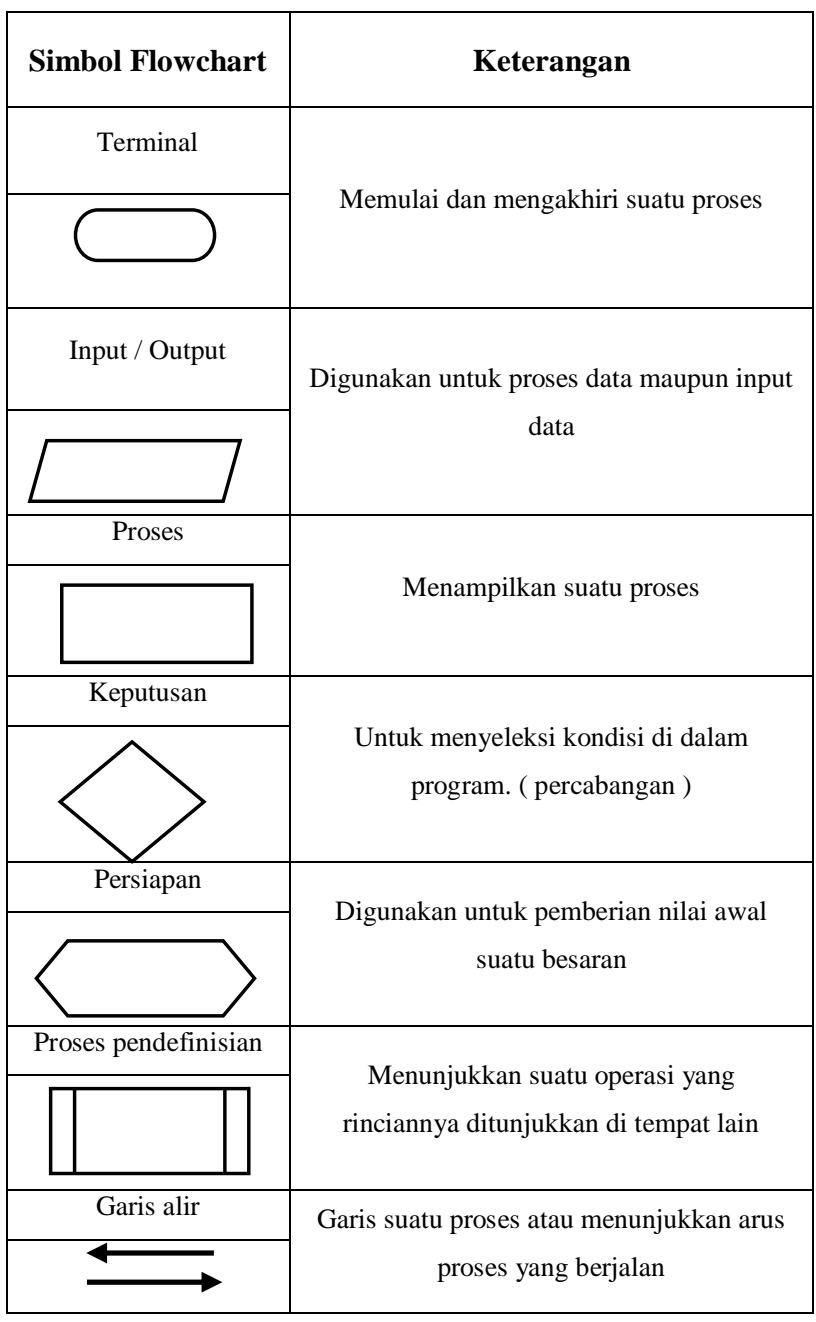

\section{T. Entity Relationship Diagram}

Entitas yang ada pada suatu sistem umumnya banyak. Antar entitas memiliki hubungan (Lihat Tabel VI). Hubungan antar entitas biasa dinyatakan dengan Diagram Hubungan Entitas (Entity Relationship Diagram - ERD). Diagram Entitas Ekternal Proses Data Store ini hanya menggambarkan hubungan antar entitas atau data dan tidak menggambarkan proses dari suatu sistem. Hubungan atau relasi antar entitas dengan entitas lainnya menggunakan bentuk "diamond" [17].

TABEL VI

SIMBOL ERD

\begin{tabular}{|c|c|}
\hline \multirow[t]{5}{*}{ Simbol ERD } & Keterangan \\
\hline & $\begin{array}{c}\text { Entitas : } \\
\text { Memberikan identitas yang mewakili suatu } \\
\text { objek dan dapat dibedakan dengan objek } \\
\text { yang lain. }\end{array}$ \\
\hline & $\begin{array}{c}\text { Relasi : } \\
\text { Menunjukkan hubungan di antara sejumlah } \\
\text { entitas yang berbeda. }\end{array}$ \\
\hline & $\begin{array}{c}\text { Atribut : } \\
\text { Properti yang dimiliki oleh suatu entitas, } \\
\text { di mana dapat mendeskripsikan karakteristik } \\
\text { dari entitas tersebut. }\end{array}$ \\
\hline & $\begin{array}{c}\text { Alur: } \\
\text { Garis yang memiliki fungsi untuk } \\
\text { menghubungkan atribut dengan entitas dan } \\
\text { entitas dengan relasi. }\end{array}$ \\
\hline
\end{tabular}

\section{U. Kamus Data (Data Dictionary)}

Kamus data merupakan tempat penyimpanan dari aliran-aliran data, file dan proses-proses dalam sebuah sistem. Kamus data digunakan untuk menjelaskan semua data yang mengalir atau digunakan dalam sistem, yaitu mengenai arus data yang masuk ke dalam sistem dan tentang informasi yang dibutuhkan oleh pemakai sistem.

Kamus Data adalah katalog fakta tentang data dan kebutuhan-kebutuhan informasi dari suatu sistem informasi.

Data dictionary tidak menggunakan notasi grafik sebagaimana halnya Data Flow Diagram. Kamus data berfungsi untuk membantu user agar dapat mengerti aplikasi secara rinci [4].

\section{Blackbox Testing}

Blackbox Testing atau pengujian blackbox merupakan metode uji coba yang memfokuskan pada keperluan fungsional dari software. Karena itu uji coba blackbox memungkinkan pengembang software untuk membuat himpunan kondisi input yang akan melatih seluruh syaratsyarat fungsional suatu program.

Blackbox testing berfokus pada persyaratan fungsional perangkat lunak yang memungkinkan engineers untuk memperoleh set-kondisi input yang sepenuhnya akan melaksanakan persyaratan fungsional untuk sebuah program [18]. 


\section{W. Kuesioner}

Kuesioner adalah teknik pengumpulan data dengan menyerahkan atau mengirimkan daftar pertanyaan untuk diisi sendiri oleh responden. Dalam penelitian survey, pemakaian kuesioner merupakan hal penting untuk mengumpulkan data. Analisis data kualitatif dan kuantitatif berdasarkan kuesioner tersebut. Sebuah kuesioner yang baik adalah sebuah kuesioner yang mengandung pertanyaan yang baik pula, dalam arti sedemikian sehingga tidak menimbulkan arti yang lain pada diri responden. Pertanyaan-pertanyaan yang ada pada sebuah kuesioner harus jelas dan mudah dimengerti sehingga mengurangi tingkat kesalahan interprestasi responden dalam pengisian kuesioner.

\section{MSE}

Mean Squared Error (MSE) adalah metode lain untuk mengevaluasi metode peramalan. Masing-masing kesalahan atau sisa dikuadratkan. Kemudian dijumlahkan dan ditambahkan dengan jumlah observasi. Pendekatan ini mengatur kesalahan peramalan yang besar karena kesalahan-kesalahan itu dikuadratkan. Metode itu menghasilkan kesalahan-kesalahan sedang yang kemungkinan lebih baik untuk kesalahan kecil, tetapi kadang menghasilkan perbedaan yang besar. Hasil nilai MSE terbaik adalah yang bernilai minimum [19].

\section{HASIL DAN PENGUJIAN}

\section{A. Antarmuka Pengguna}

Antarmuka pengguna merupakan antarmuka yang diakses oleh pengguna saat mengunjungi website. Antarmuka ini berisi peta Kabupaten Sintang beserta informasi sebaran penyakit rabies yang ada di Kabupaten Sintang berupa hasil perhitungan small area estimation perdesa dan titik kasus sebaran perdesa. Selain itu juga terdapat beberapa fitur persebaran rabies berdasarkan bulan dan tahun. Tampilan antarmuka pengguna dapat dilihat pada Gambar 5.

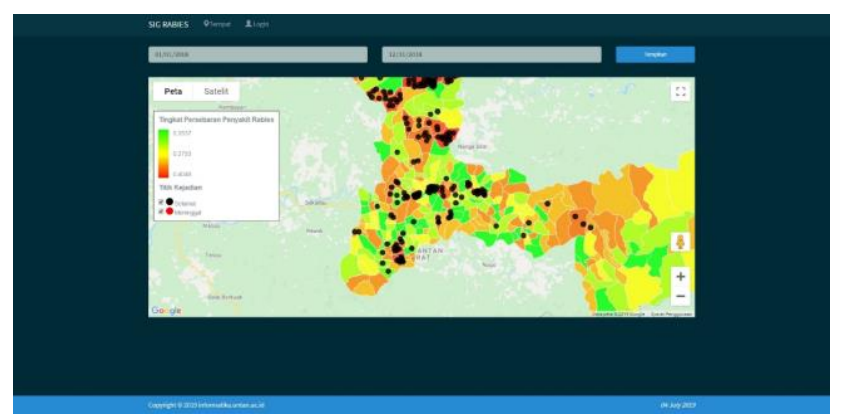

Gambar.5 Halaman antar muka user

\section{B. Output Sistem}

Hasil perhitungan atau output pada web akan dilakukan analisis dimana apakah hasil ouput sesuai dengan perhitungan yang telah dilakukan.

1. Output Hasil Perhitungan Small Area Estimation

Hasil dari perhitungan dapat dilihat pada Gambar 6 berikut dimana dapat dilihat terdapat warna yang menunjukan suatu tingkat dinyatakan aman atau berbahaya.

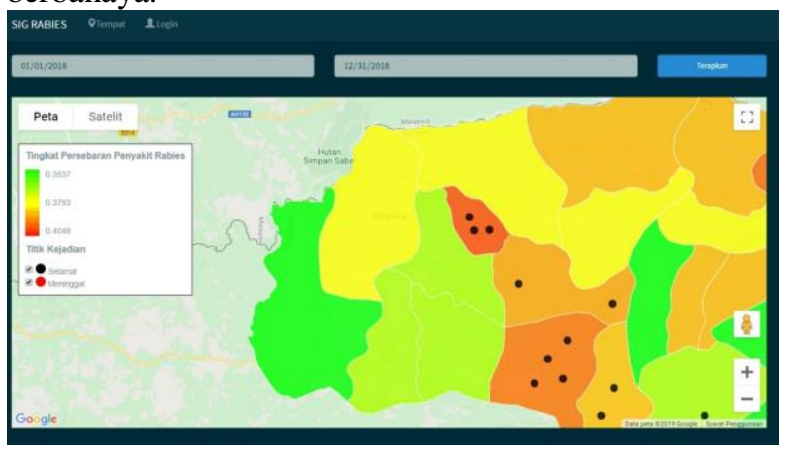

Gambar. 6 Output Hasil Perhitungan

2. Analisis Pada Daerah Dengan Status Aman

Pada peta dapat dilihat pada Gambar 7 desa Sungai Seria memiliki indikator berwana hijau dengan parameter sebagai berikut :
1. Jumlah Kasus Gigitan : 0
2. Jumlah HPR $: 17$
3. Jumlah Vaksin $: 85$
4. Presentase Rabies : : 0,0354

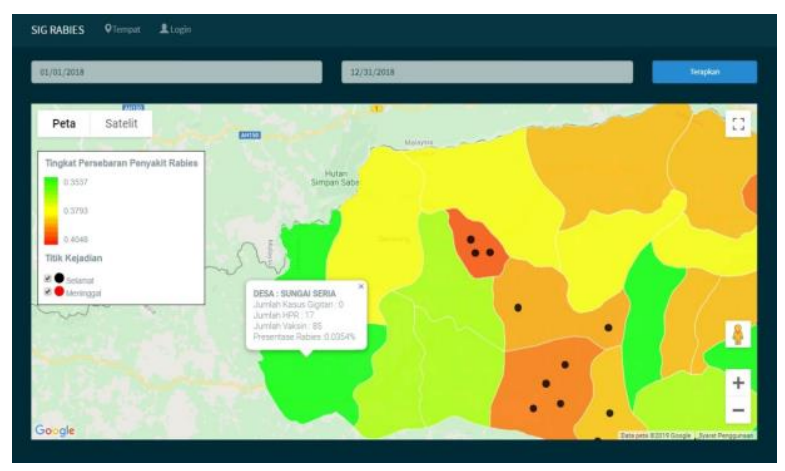

Gambar.7 Analisis pada daerah status aman

Dari hasil output pada sistem pada Gambar 7 menunjukan desa Sungai Seria pada status aman dengan nilai presentasi MSE 0,0354 dengan indikator desa berwarna hijau.

3. Analisis Pada Daerah Dengan Status Siaga

Pada peta dapat dilihat pada Gambar 8 desa Muakan Petinggi memiliki indikator berwana kuning dengan parameter sebagai berikut :
1. Jumlah Kasus Gigitan
2. Jumlah HPR
$: 0$
3. Jumlah Vaksin
$: 10$
4. Presentase Rabies

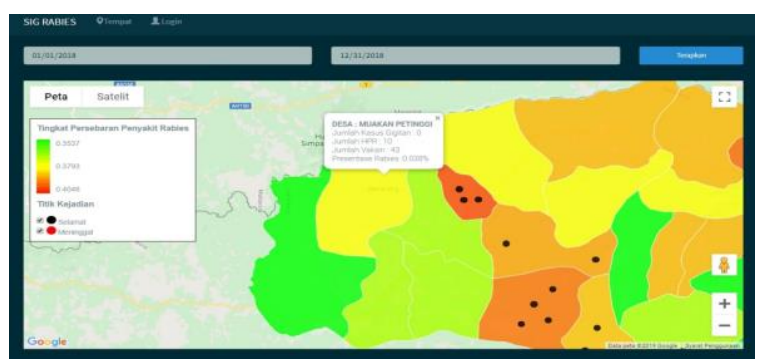

Gambar. 8 Analisis pada daerah status siaga 
Dari hasil output pada sistem pada Gambar 8 menunjukan desa Muakan Petinggi pada status siaga dengan nilai presentasi MSE 0,0398 dengan indikator desa berwarna kuning.

4. Analisis Pada Daerah Dengan Status Bahaya

Pada peta dapat dilihat pada Gambar 9 desa Senaning memiliki indikator berwana Merah dengan parameter sebagai berikut :

1. Jumlah Kasus Gigitan : 3

2. Jumlah HPR : 92

3. Jumlah Vaksin : 39

4. Presentase Rabies : :0,0397

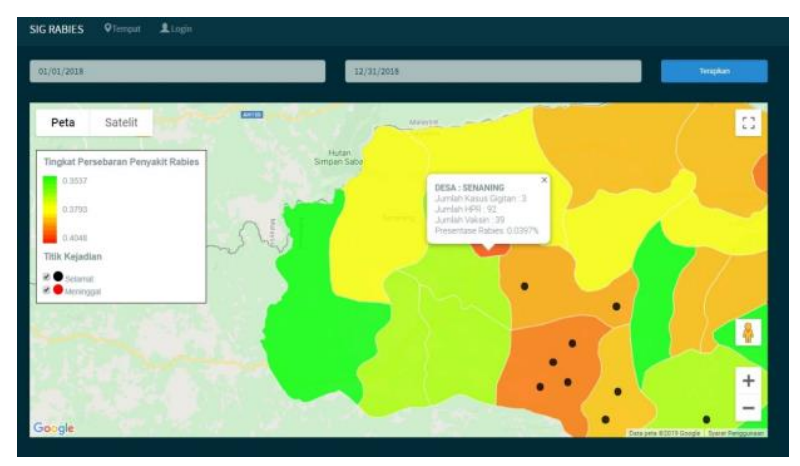

Gambar. 9 Analisis pada daerah status bahaya

Dari hasil output pada sistem pada Gambar 9 menunjukan desa Senaning pada status bahaya dengan nilai presentasi MSE 0,0397 dengan indikator desa berwarna merah.

\section{Pengujian Hasil Perhitungan}

Pengujian hasil perhitungan ini menggunakan persamaan (2.1) dan (2.2). Kemudian hasil dari perhitungan akan disesuaikan berdasarkan warna dengan code program sebagai berikut.

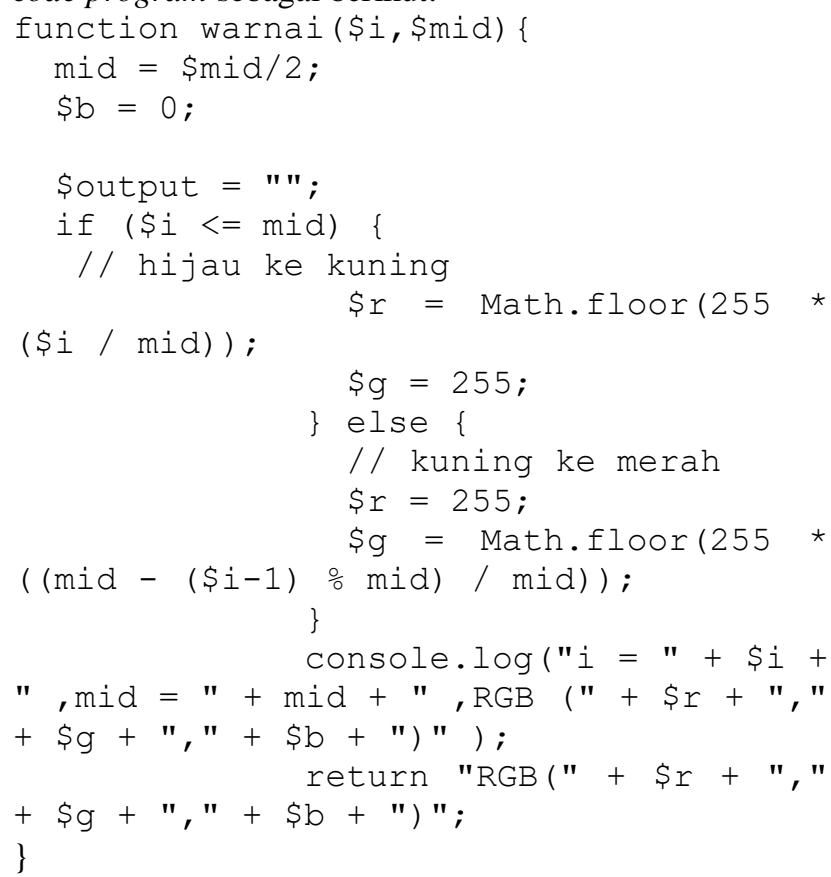

Dari code program di atas didapatkan perhitungan untuk menentukan hasil nilai MSE kedalam peta dalam bentuk warna. hijau ke kuning $=(255 *(\$ \mathrm{i} / \mathrm{mid}))$ perhitungan $(3)$

kuning ke merah $=(255 *((\operatorname{mid}-(\$ \mathrm{i}-1) \% \bmod ) / \mathrm{mid}))$ perhitungan (4)

Keterangan:

mid = Nilai tengah dari jumlah keseluruhan perhitungan MSE

i $\quad=$ Nilai MSE $* 100$

$\bmod =$ Sisa pembagian

Contoh:

hijau ke kuning desa margahayu $=(255 *(22,4 / 56)$

$=255 * 0.4$

$=102$

Dari Perhitungan di atas diperoleh desa Margahayu memiliki warna hijau dengan RGB 102,255,0. Hasil perhitungan tersebut akan diuji kesesuaiannya dengan output pada Sistem Informasi Geografis yang telah dibuat. Dapat dilihat pada Tabel VII.

TABEL VII

PENGUJIAN HASIL PERHITUNGAN

\begin{tabular}{|c|c|c|c|c|c|c|c|}
\hline \multirow[b]{2}{*}{ No. } & \multirow[b]{2}{*}{$\begin{array}{c}\text { Keca } \\
\text { matan }\end{array}$} & \multirow[b]{2}{*}{ Desa } & \multicolumn{3}{|c|}{ Indikator } & \multirow{2}{*}{$\begin{array}{c}\text { MSE } \\
\left(\theta \boldsymbol{i}^{E B}\right)\end{array}$} & \multirow{2}{*}{$\begin{array}{c}\text { Indika } \\
\text { tor } \\
\text { Warn } \\
\text { a } \\
\end{array}$} \\
\hline & & & $\begin{array}{c}X \\
1\end{array}$ & $\begin{array}{l}X \\
2\end{array}$ & $\begin{array}{l}\mathbf{X} \\
\mathbf{3}\end{array}$ & & \\
\hline 1. & $\begin{array}{c}\text { KETUN } \\
\text { GAU } \\
\text { TENGA } \\
\mathrm{H} \\
\end{array}$ & $\begin{array}{l}\text { SENANGA } \\
\text { N KECIL }\end{array}$ & 5 & 5 & 5 & $\begin{array}{c}0.0404819 \\
28\end{array}$ & Merah \\
\hline 2. & $\begin{array}{c}\text { KETUN } \\
\text { GAU } \\
\text { TENGA } \\
\text { H }\end{array}$ & $\begin{array}{l}\text { MARGAH } \\
\text { AYU }\end{array}$ & 1 & 1 & 1 & $\begin{array}{c}0,3536842 \\
1\end{array}$ & Hijau \\
\hline 3. & $\begin{array}{c}\text { KETUN } \\
\text { GAU } \\
\text { HULU }\end{array}$ & SEBADAK & 4 & 3 & 2 & $\begin{array}{c}0,0393068 \\
7\end{array}$ & Kuning \\
\hline
\end{tabular}

Berdasarkan Tabel VII dapat dilihat desa Senangan Kecil memiliki nilai MSE tertinggi 0.040481928 dan memiliki indikator warna merah. Desa Margahayu memiliki nilai MSE terendah 0,35368421 dan memiliki indikator warna hijau. Desa Sebadak memiliki nilai tengah MSE 0,03930687 dan memiliki indikator warna kuning.

\section{Pengujian Kuesioner}

Kuesioner berisi 15 pertanyaan yang dikelompokkan menjadi 3 aspek yang digunakan dalam pengujian aplikasi tersebut, yaitu aspek rekayasa perangkat lunak, aspek fungsionalitas, dan aspek tampilan. Kuesioner dibagikan kepada 15 responden yang merupakan masyarakat umum. Hasil kuesioner dirangkum berdasarkan tiga aspek yang diujikan.

1) Aspek Rekayasa Perangkat Lunak

Hasil kuesioner aspek rekayasa perangkat lunak dirangkum dalam sebuah tabel seperti pada Tabel VIII. 
TABEL VIII

HASIL KUESIONER ASPEK REKAYASA PERANGKAT LUNAK

\begin{tabular}{|c|c|c|c|c|c|c|c|}
\hline \multirow{2}{*}{ No } & \multirow{2}{*}{$\begin{array}{c}\text { Aspek } \\
\text { Rekayasa } \\
\text { Perangkat } \\
\text { Lunak }\end{array}$} & \multicolumn{5}{|c|}{ Tanggapan } & \multirow{2}{*}{$\begin{array}{l}\text { To } \\
\text { tal }\end{array}$} \\
\hline & & 1 & 2 & 3 & 4 & 5 & \\
\hline 1 & $\begin{array}{l}\text { Kemudahan } \\
\text { akses web }\end{array}$ & 0 & 0 & 2 & 9 & 4 & 15 \\
\hline 2 & $\begin{array}{l}\text { Kompatibilitas } \\
\text { web dengan } \\
\text { browser }\end{array}$ & 0 & 0 & 0 & 8 & 7 & 15 \\
\hline 3 & $\begin{array}{l}\text { Kemudahan } \\
\text { menggunkan } \\
\text { fitur-fitur pada } \\
\text { web }\end{array}$ & 0 & 0 & 0 & 5 & 10 & 15 \\
\hline 4 & $\begin{array}{l}\text { Kemudahan } \\
\text { kontrol web }\end{array}$ & 0 & 0 & 0 & 11 & 4 & 15 \\
\hline 5 & $\begin{array}{l}\text { Kenyamanan } \\
\text { penggunaan } \\
\text { web }\end{array}$ & 0 & 0 & 0 & 7 & 8 & 15 \\
\hline & Jumlah & 0 & 0 & 2 & 40 & 33 & 75 \\
\hline \multicolumn{2}{|c|}{ Persentase $(\%)$} & $\begin{array}{l}0 \\
\%\end{array}$ & $\begin{array}{l}0 \\
\%\end{array}$ & $\begin{array}{l}3 \\
\%\end{array}$ & $\begin{array}{l}53 \\
\%\end{array}$ & $\begin{array}{l}44 \\
\%\end{array}$ & $\begin{array}{c}10 \\
0 \%\end{array}$ \\
\hline
\end{tabular}

Keterangan: $\quad 1=$ Sangat buruk

$2=$ Buruk

3 = Cukup baik

$4=$ Baik

$5=$ Sangat baik

2) Aspek Fungsionalitas

Hasil kuesioner aspek fungsionalitas dirangkum dalam sebuah tabel seperti pada Tabel IX.

TABELIX

TABEL HASIL KUESIONER ASPEK FUNGSIONALITAS

\begin{tabular}{|c|c|c|c|c|c|c|c|}
\hline \multirow{2}{*}{ No } & \multirow{2}{*}{ Aspek Fungsionalitas } & \multicolumn{5}{|c|}{ Tanggapan } & \multirow{2}{*}{$\begin{array}{c}\text { Tota } \\
1\end{array}$} \\
\hline & & 1 & 2 & 3 & 4 & 5 & \\
\hline 1 & $\begin{array}{l}\text { Kinerja web dalam } \\
\text { menampilkan peta } \\
\text { berdasarkan metode } \\
\text { small area estimation }\end{array}$ & 0 & 0 & 0 & 7 & 8 & 15 \\
\hline 2 & $\begin{array}{l}\text { Kinerja web dalam } \\
\text { memberikan informasi } \\
\text { berupa persentase } \\
\text { sebaran berdasarkan } \\
\text { jumlah penduduk di } \\
\text { masing-masing desa }\end{array}$ & 0 & 0 & 1 & 6 & 8 & 15 \\
\hline 3 & $\begin{array}{l}\text { Kinerja web dalam } \\
\text { memberikan informasi } \\
\text { berupa persentase } \\
\text { sebaran berdasarkan } \\
\text { jumlah titik kasus di } \\
\text { masing-masing desa }\end{array}$ & 0 & 0 & 1 & 6 & 8 & 15 \\
\hline 4 & $\begin{array}{l}\text { Kinerja web dalam } \\
\text { memberikan detail } \\
\text { informasi } \\
\text { masing-masing desa }\end{array}$ & 0 & 0 & 0 & 7 & 8 & 15 \\
\hline 5 & $\begin{array}{lr}\text { Kinerja web } & \text { dalam } \\
\text { memberikan } & \text { detail } \\
\text { informasi } & \text { pada } \\
\text { masing-masing } & \text { titik } \\
\text { kasus } & \\
\end{array}$ & 0 & 0 & 0 & 7 & 8 & 15 \\
\hline & Jumlah & 0 & 0 & 2 & 33 & 40 & 75 \\
\hline & Persentase (\%) & $\begin{array}{l}0 \\
\%\end{array}$ & $\begin{array}{l}0 \\
\%\end{array}$ & $\begin{array}{l}3 \\
\%\end{array}$ & $44 \%$ & $\begin{array}{l}53 \\
\%\end{array}$ & $\begin{array}{c}100 \\
\%\end{array}$ \\
\hline
\end{tabular}

Keterangan: $\quad 1$ = Sangat buruk

$$
2=\text { Buruk }
$$

3 = Cukup baik

4 = Baik

5 = Sangat baik

3) Aspek Tampilan

Hasil kuesioner aspek tampilan dirangkum dalam sebuah tabel seperti pada Tabel 10.

TABEL $X$

TABEL HASIL KUESIONER ASPEK TAMPILAN

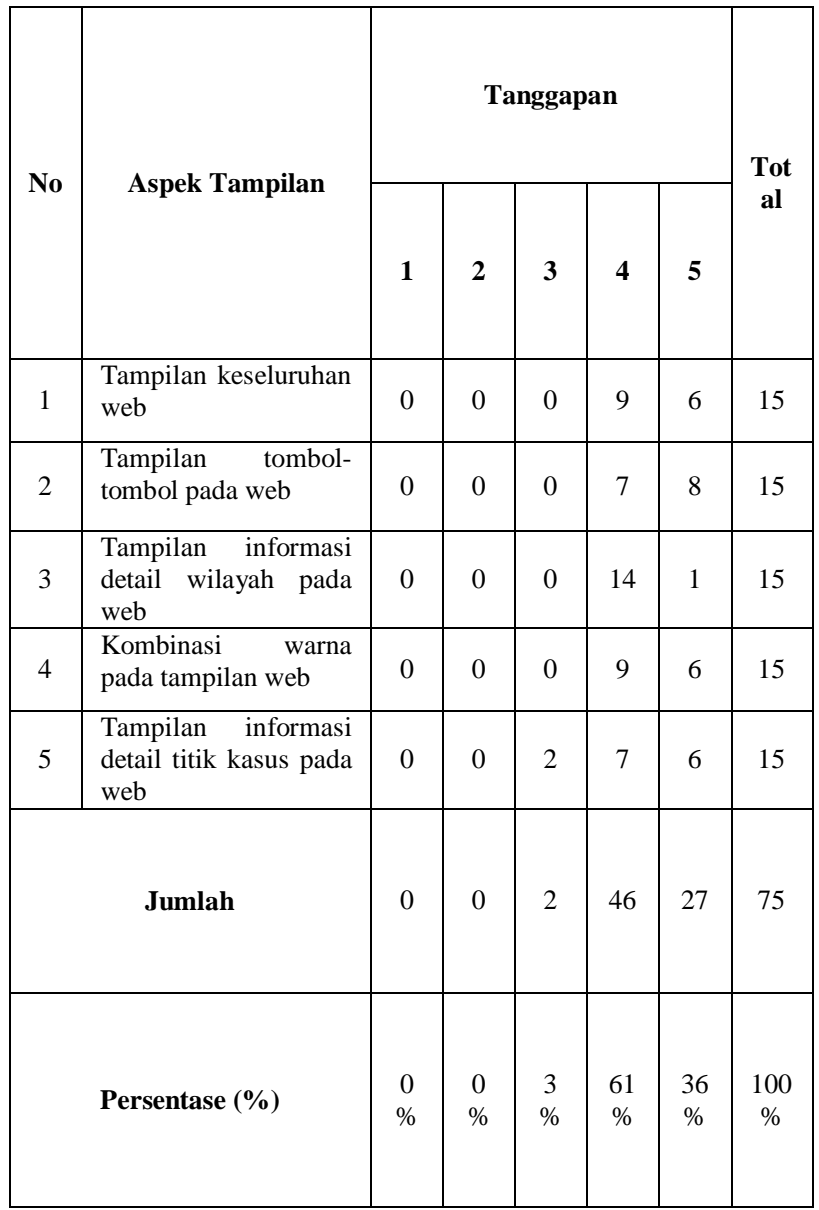

Keterangan: $\quad 1=$ Sangat buruk

$$
2=\text { Buruk }
$$

3 = Cukup baik

4 = Baik

5 = Sangat baik

Hasil kuesioner yang telah dirangkum berdasarkan aspek pengujian tersebut akan dihitung jumlah dan persentase (\%) dari tanggapan seluruh responden. Dari persentase yang telah didapat, akan dibuat diagram lingkaran sebagai visualisasi setiap aspek hasil kuesioner.

Untuk mengetahui tingkat keberhasilan aplikasi dari kuesioner, digunakan metode Likert's Summated Rating (LSR) untuk mengukur skor terkecil dan terbesar dari 15 pertanyaan kuesioner yang ditanggapi oleh responden. Skor tanggapan dari 15 pertanyaan untuk setiap responden dirangkum dalam sebuah tabel seperti pada Tabel 11 berikut. 
TABEL XI

TABEL SKOR RESPONDEN

\begin{tabular}{|c|c|c|c|c|c|c|c|c|c|c|c|c|c|c|c|c|}
\hline \multirow{2}{*}{$\begin{array}{l}\text { Respon } \\
\text { den }\end{array}$} & \multicolumn{15}{|c|}{ Item } & \multirow{2}{*}{$\begin{array}{l}\text { To } \\
\text { tal }\end{array}$} \\
\hline & 1 & 2 & 3 & 4 & 5 & \begin{tabular}{|l|}
6 \\
\end{tabular} & 7 & 8 & 9 & 10 & 11 & 12 & 13 & 14 & \begin{tabular}{|l|l}
15 \\
\end{tabular} & \\
\hline A & 4 & 4 & 5 & 4 & 5 & 4 & 3 & 4 & 5 & 4 & 5 & 4 & 4 & 5 & 5 & 65 \\
\hline B & 5 & 4 & 4 & 4 & 5 & 5 & 5 & 3 & 4 & 4 & 4 & 5 & 4 & 4 & 3 & 63 \\
\hline $\mathrm{C}$ & 4 & 5 & 4 & 4 & 4 & \begin{tabular}{|l|}
4 \\
\end{tabular} & 5 & \begin{tabular}{|l|}
5 \\
\end{tabular} & 5 & 4 & 4 & 5 & 4 & 4 & 4 & 65 \\
\hline D & 4 & 5 & 5 & 4 & 4 & 5 & 4 & 5 & 4 & 4 & 5 & 4 & 4 & 4 & 5 & 62 \\
\hline E & 3 & 4 & 5 & 4 & 5 & 4 & 4 & 4 & 5 & 4 & 5 & 5 & 4 & 5 & 3 & 64 \\
\hline$F$ & 5 & 5 & 5 & 4 & 5 & 5 & 5 & 4 & 4 & 4 & 4 & 5 & 4 & 5 & 5 & 69 \\
\hline G & 4 & 5 & 4 & 4 & 4 & 5 & 5 & 4 & 5 & 4 & 5 & 4 & 4 & 4 & 4 & 65 \\
\hline $\mathrm{H}$ & 4 & 4 & 4 & 5 & 4 & 4 & \begin{tabular}{|l|}
5 \\
\end{tabular} & \begin{tabular}{|l|}
5 \\
\end{tabular} & 4 & 5 & 5 & 5 & 4 & 4 & 4 & 66 \\
\hline I & 4 & 5 & 4 & 5 & 5 & 5 & \begin{tabular}{|l|}
5 \\
\end{tabular} & \begin{tabular}{|l|}
5 \\
\end{tabular} & 5 & 5 & 4 & 4 & 5 & 4 & 4 & 69 \\
\hline $\mathrm{J}$ & 4 & 5 & 5 & 4 & 5 & 4 & \begin{tabular}{|l|}
4 \\
\end{tabular} & \begin{tabular}{|l|}
5 \\
\end{tabular} & 4 & 5 & 5 & 5 & 4 & 5 & 4 & 68 \\
\hline $\mathrm{K}$ & 5 & 5 & 5 & 4 & 4 & 5 & \begin{tabular}{|l|}
4 \\
\end{tabular} & 4 & 5 & 5 & 5 & 5 & 4 & 4 & 4 & 67 \\
\hline L & 4 & 4 & 5 & 5 & 4 & 4 & \begin{tabular}{|l|}
4 \\
\end{tabular} & \begin{tabular}{|l|}
4 \\
\end{tabular} & 4 & 5 & 4 & 4 & 4 & 5 & 4 & 64 \\
\hline $\mathrm{M}$ & 3 & 4 & 5 & 5 & 5 & 5 & \begin{tabular}{|l|}
5 \\
\end{tabular} & \begin{tabular}{|l|}
5 \\
\end{tabular} & 5 & 5 & 4 & 5 & 4 & 4 & 5 & 69 \\
\hline $\mathrm{N}$ & 4 & 4 & 5 & 4 & 5 & \begin{tabular}{|l|}
4 \\
\end{tabular} & \begin{tabular}{|l|}
4 \\
\end{tabular} & \begin{tabular}{|l|}
5 \\
\end{tabular} & 4 & \begin{tabular}{|l|}
5 \\
\end{tabular} & 5 & 5 & 4 & 5 & 5 & 68 \\
\hline 0 & 5 & 4 & 5 & 4 & 4 & 5 & \begin{tabular}{|l|}
5 \\
\end{tabular} & \begin{tabular}{|l|}
5 \\
\end{tabular} & 5 & 5 & 5 & 4 & 4 & 4 & 5 & 69 \\
\hline \multicolumn{16}{|c|}{ Total Skor } & $\begin{array}{l}99 \\
3\end{array}$ \\
\hline
\end{tabular}

1. Jumlah skor untuk setiap responden:

- skor maksimal $=75$ (5 x 15 item $)$

- $\quad$ skor minimal $=15(1 \times 15$ item $)$

- skor median $=45(3 \times 15$ item $)$

- skor kuartil I = $30(2 \times 15$ item $)$

- skor kuartil III = 60 (4 x 15 item $)$

2. Jumlah skor untuk seluruh responden:

- Maksimal $=1125(15 \times 75)$

- Minimal $=225(15 \times 15)$

- Median $=675(15 \times 45)$

- Kuartil I = $450(15 \times 30)$

- Kuartil III = 900 (15 x 60)

3. Interpretasi jumlah skor tersebut adalah:

- $900<$ Skor < 1125, artinya sangat baik.

- $675<$ Skor < 900, artinya baik.

- $450<$ Skor < 675, artinya tidak baik.

- $225<$ Skor < 450, artinya sangat tidak baik.

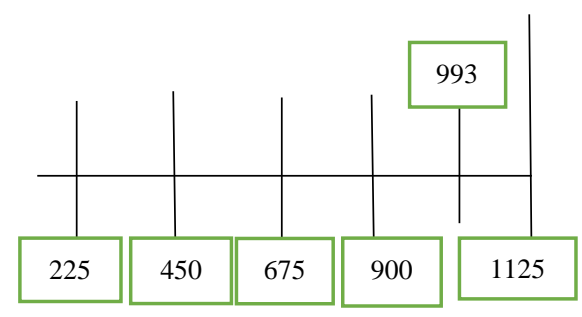

Gambar.13 Hasil Kuesioner Pada Interpretasi LSR

Gambar 13 menunjukkan bahwa hasil perhitungan kuesioner pada interpretasi Likert's Summated Rating (LSR) adalah 993 yang berada di antara skor 900 dan 1125.

\section{KESIMPULAN}

Penelitian yang dilakukan menghasilkan sistem informasi geografis dengan menggunakan metode small area estimatiton. Sehingga dapat menentukan desa-desa yang dalam kondisi bahaya rabies.

Dalam menentukan daerah yang berpotensi menjadi pusat penyakit rabies ditentukan berdasarkan data statistik yang ada dengan parameter yang didapat melalui perhitungan korelasi regresi untuk melihat apakah parameter-parameter tersebut mempunyai hubungan dengan kasus rabies di Kabupaten Sintang. Parameter yang bernilai positif adalah jumlah kasus gigitan, jumlah penderita rabies, dan jumlah vaksin pada masing- masing desa di Kabupaten Sintang.

Dari hasil output pada sistem yang telah dibuat menunjukan bahwasannya daerah yang saling bertetangga belum tentu juga berpotensi tinggi untuk terjadinya rabies di karenakan parameter rabies yang telah ditentukan.

Berdasarkan dari hasil pengujian metode Small Area Estimation terdapat 3 desa menjadi prioritas dengan status bahaya penyakit rabies desa Senangan Kecil, Tanjung Puri, dan Kapuas Kanan Hulu dengan nilai MSE 0,040481928. Nilai MSE yang semakin jauh dari 0 menunjukan daerah tersebut dalam status sangat berbahaya.

Hasil pengujian dengan Blackbox menunjukan fungsifungsi dan fitur-fitur yang terdapat pada sistem informasi geografis yang dibangun berjalan sesuai dengan yang diharapkan.

Hasil dari pengujian kuesioner, dengan 15 orang responden memiliki persentase dengan rata-rata $88 \%$ yang berdasarkan skala likert menunjukan bahwa sistem informasi geografis persebaran penyakit rabies di kabupaten Sintang menggunakan metode small area estimation berada pada kategori sangat baik.

\section{DAFTAR PUSTAKA}

[1] R. R. Putri, "Perancangan Sistem Pemanfaatan Lahan untuk Perkebunan dengan Metode Small Area Estimation (SAE)," JUSTIN (Jurnal Sistem dan Teknologi Informasi), 2014.

[2] J. N. K. Rao, Small Area Estimation, New York: John Wiley and Sons, 2003.

[3] R. Machmud, "Peranan Penerapan Sistem Informasi Manajemen Terhadap Efektivitas Kerja Pagawai Lembaga Pemasyarakatan Narkotika (Lapastika) Bollangi Kabupaten Gowa," Jurnal Capacity STIE AMKOP Makasar, vol. IX, no. 2, pp. 409-421, 2013.

[4] E. Sutanta, Sistem Informasi Manajemen, Yogyakarta: Graha Ilmu, 2009.

[5] Sutarbi, Konsep Sistem Informasi, Yogyakarta: Andi, 2004.

[6] E. Budiyanto, Sistem Informasi Georafis Menggunakan ArcView GIS, Yogyakarta: Andi, 2002.

[7] A. Kurnia, "Prediksi Terbaik Empirik Untuk Model Tranformasi Logaritma Di Dalam Pendugaan Area Kecil Dengan Penerapan Pada Data Susenas," Disertasi. Pascasarjana, IPB, Bogor, 2009.

[8] R. Fay and R. Herriot, "Estimates Income for Small Places: An Application of James-Stein Procedures to Census Data. Journal of American Statistical Association," Journal of American Statistical Association, pp. 269-277, Herriot, R.A..

[9] H. Usman and Purnomo, Metodologi Penelitian Sosial, Jakarta: PT Bumi Aksara, 2008.

[10] Jayan, CSS Untuk Orang Awam, Palembang: Maxikom, 2010.

[11] Anhar, Panduan menguasai PHP \& MySQL secara otodidak, Jakarta: Mediakita, 2010.

[12] W. Komputer, Belajar Javascript Menggunakan JQuery, Andi Publisher, 2012.

[13] Arbie, Manajemen Database Dengan MySQL, Yogyakarta: Andi, 2004.

[14] B. Hariyanto, Konsep dan Tuntunan Praktis Basis Data, Yogyakarta: Andi, 2004.

[15] Indrajani, Perancangan Basis Data dalam All in 1, Jakarta: PT. Elex Media Komputindo, 2011.

[16] H. Jogiyanto, Analisis \& Desain Sistem Informasi Pendekatan Terstruktur Teori dan Praktek Aplikasi Bisnis, Yogyakarta: Andi, 2005. 
[17] A. Kadir, Dasar Pemrograman Web Dinamis Menggunakan PHP, Yogyakarta: Andi, 2008.

[18] R. S. Pressman, Rekayasa Perangkat Lunak Pendekatan Praktisi (Buku Satu), Yogyakarta: Andi, 2010.

[19] J. Heizer and B. Render, Manajemen Operasi, Jakarta: Salemba, 2009. 